\title{
4 \\ Brij V. Lal: Rooting for History
}

\section{Goolam Vahed}

I have come to the conclusion after a lifetime of reading and writing that accessible prose is valued by the lay reader. Stories draw people in. Storytelling, as Hannah Arendt once wrote, 'reveals meaning without committing the error of defining it'. The sharing of experience creates the possibilities for individual acts of imagination ... Imaginative works have that special power to connect (Lal 2011: 5; see also Arendt 1968: 105).

Having keenly followed Brij V. Lal's work on indenture since the 1980s, I was delighted when he invited me to contribute a chapter on South Africa for The Encyclopaedia of the Indian Diaspora (Lal 2006: 6). I teamed up with Surendra Bhana and we were two of the many scholars worldwide who contributed to the Encyclopaedia, which has received rave reviews. Thus began my relationship with a scholar whose life's work has inspired many individuals. We met for the first time in 2010 when he visited South Africa with his wonderful wife, Padma. We subsequently met at conferences in Mauritius in December 2011 and at Hyderabad in February 2013 where he presented carefully crafted lectures.

Although Lal is an internationally recognised scholar, his demeanour reflected his humble roots. He hails from Tabia, Labasa; the son of a petty cane farmer whose parents had no formal education. He was modest about his own academic contributions, but a cheerful soul. In Mauritius, we sat with scholars from Suriname, the Netherlands, and Trinidad deep into the night chatting about matters ranging from Bollywood to contemporary politics and the state of world cricket, while some took to singing Hindi 
film songs and ghazals. We in South Africa have largely adopted English as our home language and it was a revelation that Indian languages are alive in some of the former colonies where indentured Indians had emigrated.

Lal established a formidable reputation as a scholar on indentured labour in Fiji. His work evolved over the years and he has written prolifically and passionately on contemporary politics in the land of his birth. His books on Fiji include its twentieth-century political history, a biography of the Indo-Fijian leader A.D. Patel, an analysis of that country's coups in recent decades, and an account of constitutionalism in post-coup Fiji. Lal's scholarship and activism is widely acknowledged and he has received a string of academic and civic honours. He was elected a Fellow of the Australian Humanities Academy in 1996; appointed to the Fiji Constitution Review Commission in 1996; awarded the Officer of the Order of Fiji in 1998; promoted to full Professor in the Institute of Advanced Studies at The Australian National University (ANU) in the same year; awarded a 25th Anniversary of Fiji Independence Medal in recognition of his contribution to Fijian education; and was made a Member of the Order of Australia (AM) for his contribution to the promotion of Pacific scholarship through research and commentary. He was also banned from his homeland, a painful experience; he wrote, 'I now live forcibly exiled from the land of my birth' (Lal 2011: 6).

I first encountered Lal's works as a graduate student at Indiana University where, as a Fulbright student, I completed my Master's and Doctoral degrees. A class on bonded labour gave me the opportunity to research Indian indenture and I read up on current literature. ${ }^{1}$ This began to broaden my understanding of the Indian diasporic experience. I also became acquainted with the influential works of E.P. Thompson, especially his monumental and pathbreaking study, The Making of the English Working Class (1963). ${ }^{2}$ The work of this towering figure in labour history was liberating when juxtaposed with Louis Althusser and other

1 The earliest conference on Indian indenture was held in Mauritius in 1984. It was attended by Hugh Tinker and by scholars from the Caribbean and South Africa. This created a network of scholars working on indenture. Some of the papers were published in the collection edited by Uttama Bissoondoyal and S.B.C. Servansing (1986). Scholars like David Dabydeen, Brinsley Somaroo, Basdeo Mangru, Rhoda Reddock, Madhavi Kale and Marianne Ramesar pioneered the study of indenture in the Caribbean. Some of their early work was published in David Dabydeen and Brinsley Somaroo (1987). These studies focused on the economic contribution of indentured workers, control and resistance, the impact of the imbalanced gender ratio, folk songs, and family life.

2 The 50th anniversary of The Making of the English Working Class generated considerable discussion and commemoration. See e.g. Holland and Phillips 2014. 
structuralist and functionalist interpretations that downplayed both workers' experiences and their ability to effect social change (see Elliott 2006). I also familiarised myself with the literature on slavery in the Americas, the work of James C. Scott on resistance (1985), and the emerging work of the Subaltern Studies Collective (Chaturvedi 2000), to get a better understanding of the history of bonded labour, industrial workers and the subalterns more generally. The lesson we took from these readings was that the working class, as Thompson tells us, 'made itself as much as it was made' (1963: 194). Many of these insights were applied in revisionist studies of Indian indenture.

Indentured migration to Natal was part of a new international circulation of labour that evolved after the British abolished slavery in 1833 . To address the labour shortage on colonial plantations, around 1.3 million Indian contract labourers were exported to Mauritius, Jamaica, British Guiana, Trinidad, St Lucia, Granada and Natal between 1834 and 1916 (Y.S. Meer 1980; Northrup 1995: 156-57). Ironically, abolitionists were able to end the 'savagery' of slavery in part because of the availability of other forms of unfree labour that would come to be considered 'savage' in settler colonies (Singh 2014: 227). The 60,945 indentured migrants who went to Fiji between 1879 and 1916 constituted a tiny proportion of the overall number. The Pacific made up a small segment of the global trade in Indian indentured labourers.

Hugh Tinker's pioneering study, A New System of Slavery, provided a broad overview of indenture (1974). It was not the first such study. C. Kondapi (1951) preceded Tinker by two-and-a-half decades but Tinker (1921-2000) brought an activist bent to his subject (Munro 2009: 249-50). He had fought in the Indian army during World War II and worked in the Indian civil service before returning to England where he completed his doctoral degree at Cambridge University. He was a prolific author and academic who taught at Rangoon University and the School of Oriental and African Studies (SOAS). A New System of Slavery resonated with many left-leaning academics and activists during a time of global activism against the Vietnam War, civil rights in the USA, apartheid in South Africa, and more generally against underdevelopment in the so-called 'Third World'.

Tinker followed in the footsteps of other authors of studies of slavery in the United States where the period after the publication of Kenneth Stampp's The Peculiar Institution in 1956 saw an outpouring of scholarly 
works on slavery, the slave trade and resistance with a revisionist approach that gave the slaves voice and agency. Eugene Genovese's Roll, Jordan, Roll (1976), as well as the work of James C. Scott (1985), widened the definition of resistance to include those aspects of life that helped slaves to reclaim their humanity, such as culture, spirituality, materiality, desertion, music and work slowdowns.

Tinker viewed Indian indenture as simply an extension of slavery. This magisterial work stimulated studies of Indian indenture that sought to combine empathy for the indentured with solid empirical scholarship based on conventional archival sources such as correspondence between officials and commissions of inquiry (in the absence of memoirs, letters, diaries and other such sources). There was little by way of oral interviews with surviving indentured migrants. Tinker did not draw from studies that gave agency to the subaltern slave community, and by describing indenture as slavery he ignored the historically specific context in which indenture took place, namely colonialism (Singh 2014: 227).

Despite its shortcomings, A New System of Slavery was welcomed by many in the 'Third World' because of its focus on labour, race and class, and its clearly ideological and moral overtones. It stimulated works that expanded existing historiography in their ambition and scope. The prevailing work had focused on the workings of the system, including the legislation surrounding indenture and the horrible treatment meted out to many of the indentured (L.M. Thompson 1952; Weller 1968). In South Africa, early history writing was dominated by white scholars who showed little interest in the indentured experience. Some attention was given to Mohandas K. Ghandi's 21 years in South Africa but, overall, the emphasis was on the struggle against white minority rule. Regrettably, the opportunity to record oral histories of indentured immigrants was lost.

Lal differed from this scholarship in a very important respect. He established that knowledge of Indian origins was key to understanding the indentured experience. Decolonisation and concern with 'race relations' in the colonies in the 1950s and 1960s resulted in most studies on Indians focusing on the migrant population in the colonies rather than from whence they came. Much of this work was undertaken by anthropologists and sociologists. Historians who studied the indentured period tended to focus on the economic contribution of indentured labour, employer control on the plantations, the implications of the disparities in the gender ratio, and so on. There was little systematic profiling of the indentured populations or an exploration of their agency and lived experiences. 
When Lal conducted his research for his $\mathrm{PhD}$ at ANU from 1977, there was little information available on Fiji, apart from his $\mathrm{PhD}$ supervisor's monograph, Fijis Indian Migrants (Gillion 1962). Lal was curious to find out whom the indentured were, why they left India, and how they reconstructed their lives in Fiji, and he pioneered a study to find such information. He initially employed quantification to supplement conventional official archival sources such as the records of various government departments and commissioned reports. He analysed the Emigration Passes that contained information concerning the name, indentured number, next of kin, caste, age, gender and district of origin of migrants. This personal information was recorded by the colonial state to identify and track migrants' employment in the colonies and to monitor them in the event that they returned to India. Of the 60,000 migrants to Fiji, around 45,000 departed from Calcutta and it is on this group that Lal focused. The work was tedious. He spent 12 hours a day for five months viewing a microfiche machine in the dark room at the National Library of Australia. He analysed the passes, then coded them and analysed them via a computer that was, of course, a very basic machine in the 1970s (Munro 2009: 249).

While quantification has its critics, and like all historical sources is open to bias and misrepresentation, Lal pointed out in a subsequent study that his aim:

unlike that of others who had worked on the records of overseas Indians, was to illuminate detailed aspects of the background of the indentured emigrants, and to identify every minute shift in trends, which had been of secondary importance to other researchers. To do this effectively required the examination of all the passes. It was, it must be admitted, an extremely tedious process, but the data that the analysis has yielded has not only opened up new areas for discussion but has also given me a solid base to pursue further research into the evolution of Fiji Indian society (Lal 1983b: 44).

The outcome of Lal's research was a two-volume doctoral dissertation (1980), a condensed version of which was published as Girmityas (1983a). These studies profiled the North Indian indentured population to Fiji. The picture that emerged, he wrote, 'goes against many assumptions and assertions that have been made about the emigrants' (Lal 1983b: 45). As he would note, the 'origins' challenged the prevailing idea that the girmitiyas were from the lowest strata of society. He found that the 
migrants represented a cross-section of rural Indian society. They were members of various castes, hailing from Bihar, the Indo-Gangetic plains, and surrounding areas.

While Lal may not have consciously been thinking about this, his findings served an important political purpose for segments of the Indian diaspora. During my visits to Australia from around 2004 and subsequent attendance at conferences of the Indian diaspora, I was struck by the differences in attitude towards India and Indian academics between Indian South Africans and many of those from other former colonies who believe that Indians from India look down upon them as having low-caste indentured origins and as people who have lost their 'authentic' culture, caste and religious practices (see Vahed 2007). The difference may be due to the fact that Mohandas K. Gandhi spent the years from 1893 to 1914 in South Africa, as a result of which India has always taken a special interest in the Indian diaspora in South Africa. This included the appointment of an Agent-General by the Indian government, who liaised between Indians and the government in South Africa between 1927 and 1946, and India's support for the anti-apartheid struggle, which began with India taking up this issue at the United Nations (Vahed 2015). My perception is that South Africans are generally much less critical of India and Indian academics. Lal's findings on the caste origins of indentured migrants would have helped to demolish many of the myths around origins.

Once he established the areas from whence the migrants came, Lal spent a year in India visiting them-places such as Balia, Baharaich, Ghazipur, Faizabaad, Gonda, Gorakhpur, Sultanpur and Azamgarh-to find out what motivated people to leave. He conducted extensive oral history interviews with the descendants of indentured emigrants and found that his informants frequently spoke of the recruiters' lies and deception. More important to Lal was that, as a result of his fieldwork, he acquired a deeper understanding of the migratory experience. He found that rural Indians had historically been on the move to places such as Assam and Calcutta or Mumbai for work. The idea of going out in the world in search of employment was therefore not a new one. Many thought that Fiji was somewhere near Calcutta and that they would return home after a short sojourn. In most cases, the journey into indenture became permanent emigration. Lal's 'history by numbers' was crucial for subsequent studies that explored other aspects of indentured life. 
In Natal, for example, Surendra Bhana and Joy Brain, historians at the former University of Durban-Westville, embarked on a project in the early 1980 s to computerise Natal's ships' lists. In 1986, when they had captured 95,382 names, they fed this information into a computer programme and undertook a statistical analysis. By this time, Bhana had read Lal's Girmityas and was in contact with him:

Lal encouraged me to produce a book, even if it was statistical. I started writing up in 1987 under great pressure since I had [by then] decided to leave for the United States. On Brij Lal's advice, I proceeded with the book. I did additional research at Berkeley and had the book published by Promilla. ${ }^{3}$

Following Bhana's departure to the United States, Brain completed the outstanding names and published the list in digital format as a CD-ROM in 2003. The personal and social details of the 152,184 indentured passengers became easily accessible to anyone with internet access when the data was posted onto the University of KwaZulu-Natal, GandhiLuthuli Documentation Centre's website in 2005. When Cassim Badsha, a retired computer programmer with a passion for history, got his first glimpse of the lists, the PDF files presented themselves as an opportunity: 'It was a like a goldmine of easily accessible data for a programmer to develop a relational data base ... The value of a relational database in this form is in its capacity to generate statistics-correlations, trends, and the like-with a few clicks of a mouse' (Waetjen and Vahed 2014: 67). This promises new ways of reading existing information.

Statistics-wise we can now say so much more-like how many people died of suicides or drownings and hangings and snake bites and things like that—it's all recorded there ... The data files ha[d] never been aggregated into one. Having done this, through this programme, and having stripped key areas and linked them to the total file, like doing searches by specific village or caste or ship etc. etc. has now given all the data greater meaning ... Just those flat ships lists are pretty meaningless until you do this data mining ... Now it is all available and it can be used as a subject content at high schools, at universities, by economists, by sociologists (Waetjen and Vahed 2014: 68). ${ }^{4}$

3 Surendra Bhana, email to author, 28 May 2013, cited in Waetjen and Vahed (2014: 60).

4 This section of the chapter is drawn from Waetjen and Vahed (2014: 65-69). 
The data lists, as they currently stand, open up new and exciting possibilities for research. Badsha met with Goolam Vahed and Thirunagaren Moodley of the Documentation Centre at the University of KwaZulu-Natal on 6 August 2014 to discuss how to make the programme available to the general public via the Documentation Centre's website. Unfortunately, Badsha died before this project could materialise. There remains a possibility that his vision could be achieved. During October and November 2016, Julia Stephens, a Professor of History at Rutgers University in the USA, visited South Africa. She wrote to me in advance of the visit on 11 October 2016:

I've been reading your article 'Passages of Ink' on the Ships Lists, which was very helpful, and was wondering whether there has been any work in the last couple of years with Cassim Badsha's database. I'm hoping eventually to do some interactive digital mapping and data analysis of Indian migrant families, and his work sounds of great interest. I would love to be in touch with him if that was possible, although I understand from the article that he may not be well.

When I informed Dr Stephens that Badsha had passed on, she wrote on 18 October 2016:

Having recently started a new teaching position at Rutgers, which has a very large number of students form the US/South Asian diasporic community, I was really inspired by the collaborations that have been developing between family historians and scholars in Natal around these records ... When I didn't see anything online about the database, I feared that Cassim had never been able to complete the project. But I absolutely think that he was right that this is a gold mine for data analysis. I'd love to see the work he had started, and I think that I may be able to find help with continuing it. I'm just starting to learn how to do this sort of digital mapping and data analysis. I've been collaborating with people who know more, including the Center for History and Economics at Harvard. I know that a lot of people have put tons of work into generating this material, so I would want to use it in a way that does justice to their original vision.

At the time of completing this chapter I had not met Dr Stephens but I hope that with the permission and approval of Badsha's family, his project will come to fruition.

The ships' lists, as they currently stand, are used by individuals to trace their roots and by those applying for 'Overseas Citizen of India' (OCI) or 'Person of Indian Origin' (PIO) status. Like Lal, many academics of the 
Indian diaspora are constantly faced with calls for assistance to trace their indentured forebears and these lists make it possible to access this information more easily.

Remarkably, Natal has taken the global lead amongst colonies receiving indentured migrants in creating this kind of relational database. Interested scholars and others in Suriname have recorded the names of indentured migrants while around half the names of migrants to Mauritius have been captured on computer. No such initiative has been undertaken to record the names of migrants in other colonies that received indentured migrants. However, at a conference on indenture held in Mauritius in 2012, initiatives were taken to systematically computerise the ships' lists and to place the data on a global relational database. Both Lal and I were nominated to that committee. Progress has been slow because of limited resources, work commitments and, importantly, the death of Badsha, whose programming skills were key.

The field of indentured studies has made great strides over the past three decades. Lal is a restless historian. He felt that although his study based on quantification was important, it made a limited contribution to historical explanation. He found that generalisations tended to be descriptive rather than explanatory and he began to search for other sources in his quest to explain cause and effect. Lal turned to biographies to provide a sense of how the indentured migrants negotiated a system barely one step removed from slavery. From numbers, he was now turning the indentured into people with ambitions, cultures and agency even while accepting that the structural nature of indentured industrial agriculture was essentially unfree. Yet it was also a system that some migrants used to escape restrictions in Indian society or to assume positions of power (such as sirdars or sub-overseers) within prevailing power mechanisms.

Lal brought most of his essays on indenture together in his collection Chalo Jahagi ('Let's go shipmates') (Lal 2000). This work inspired many. He explored new themes using innovative sources where possible. Written with a deep sense of the personal and eschewing methodologies that strangle rather than liberate history, probably without realising it, Lal stimulated many historians of the Indian diaspora. I was one of them. Writing inside of apartheid in which the chapters on my forebears were almost always headlined, 'The Indian Problem', whose history was erased and whose very futures were hemmed in by an aggressive racist system, to read Lal was not only to read shared histories and memories, but also to read hope. 
Lal's Chalo Jahaji showed us that no matter how all-encompassing the system, people find innovative ways to challenge, work around and negotiate a life. Chalo Jahaji can be read as Lal taking his readers on a journey through indenture or taking the indentured on their journey to the colonies. The collection includes an emotive piece about Lal's journey to his ancestral village of Bahraich (Lal 2000: 25-39), as well as pathbreaking micro studies that focus on subject formation and agency. 'Kunti's Cry', for example, uses the attempted rape of an indentured woman by an overseer to examine issues of power, gender, violence and abuse on plantations. Lal also shows how this incident was used to mobilise anti-indenture activists (Lal 2000: 195-214). In addition, he translated Totaram Sanadhya's (written by his scribe, Benarsidas Chaturvedi) observations of plantation life, a rare and valuable document of the indentured period (Lal 2000: 261-72). As with good historical writing, Lal embraces C. Wright Mills' belief:

the biographies of men and women, the kinds of individuals they variously become, cannot be understood without reference to the historical structures in which the milieux of their everyday life are organized ... Whatever else he may be, man is a social and an historical actor who must be understood, if at all, in a close and intricate interplay with social and historical structures (2000: 62).

Ashwin Desai and I were similarly moved to conduct our own research on indentured labour (2010). Other excellent studies were emerging around this time, such as those by Rajend Mesthrie (1991), Marina Carter (Carter 1995, 1996; Carter and Torabully 2002) and Madhavi Kale (1998). Lomarsh Roopnaraine's study provided a more comprehensive story of bonded labour and of the continuity between slavery and indenture (2007). We were striving, like Lal in Chalo Jahaji, for a history from the bottom that did not provide the perspective of officials and the ruling classes. In the absence of oral histories, we relied on conventional archival sources such as correspondence between officials as well as commissions of inquiry. A valuable official source was the office of the Protector of Indian Immigrants, which had been set up in the 1870s following reports of the abuse of indentured workers. The Protector's files in the Natal Archives Repository contain a wealth of information on the lived experiences of the indentured, including many first-hand testimonies.

Ann Stoler correctly warns us that colonial archival documents are not neutral pieces of information but are imbricated in issues of power, control, fabrication and even memory (Stoler 2009). Instead of ignoring 
such archival evidence, however, like Lal in Chalo Jahaji, we sought the perspective of the indentured by reading these sources contrapuntally'against the grain'. Texts, as deconstruction theory tells us, have a multiplicity of meanings and archival documents are no exception. While the research was tedious, the results were rewarding. Although the viewpoints of the ruling classes are undoubtedly overpowering in archival documents, we found the voices of the subalterns through their letters to and from family in India, remittances, their complaints to the Protector, their testimony in court cases, estates records, and even such actions as feigning illnesses, desertion and suicide. These actions are important for, as Gayatri Spivak tells us, the subaltern don't always speak with words. Her influential article speaks of a woman who questions the idea of belonging to one man and articulates this by taking her life. Her death is compounded by the absence of institutions where her resistance speech could be heard with the result that her reason for taking her life was not recognised. Hence, Spivak's provocative title, 'Can the Subaltern Speak?' (1988: 271-313). Many among the indentured also committed suicide, and Lal has written extensively on these individuals who were speaking through their actions (Lal 2000: 215-38).

In Inside Indian Indenture, Desai and I revisited the idea that there was a total breakdown of family and culture amongst the indentured, resulting in alienation (see, for example, Jayawardena 1968). Our study does not reduce the story of indenture to a simple one of victimhood. We show that the indentured and their descendants lived complex lives. While we focus on working-class formation, we show that race, ethnicity, language and regional origins were all important in the making of class. We also recognise the importance of culture by examining popular culture, sport, leisure-time activities, education, religion, music, sexuality and death amongst the indentured. This combination of social and cultural history sought to provide a nuanced perspective of the indentured experience.

One example is that of indentured women, described by Hugh Tinker as a 'sorry sisterhood'. Indentured women undoubtedly faced many challenges. They were paid lower wages and received fewer food rations than men. Women were sometimes forced to append themselves to men to gain access to food. Women's burdens stretched beyond issues of sustenance and labour. Many were subjected to sexual violence and an unforgiving, dismissive system. Yet some of the stories, such as Votti's, draw our attention to the ways in which some women confronted the multiple 
layers of oppression. To compile this story, we searched the archives, examining documents of the Protector of Indian Immigrants, court records, Immigration Department records and estate papers. The result is the story of a remarkable woman who confronted indenture, although it meant consecutive terms of imprisonment; and the perils of being a single woman who refused sexual 'favours' even when it meant beatings and ridicule and who adeptly used the legal system for protection. She emerges as a strong woman who used the full range of the 'weapons of the weak' (Desai and Vahed 2010: 6-10).

There are many Vottis in our narrative. Instead of portraying indentured migrants as passive objects of an oppressive system, we identified the multiple beginnings that made up the indentured experience; power relations on the plantations; the intricate ways that the indentured resisted and accommodated the system; and the culture and community that they created within the period of indenture but also beyond. The indentured were as much agents as they were victims and silent witnesses to unfolding history.

The scholarship on indenture, as with slavery and other working class histories, continues to mature and break new and exciting ground. Coolie Woman by Gaiutra Bahadur (2013), for example, is the fascinating story of a young woman who went to Guiana (now Guyana) in the early twentieth century as an indentured migrant. The story of this single migrant, who was pregnant, was 'recovered' by her great-granddaughter. Bahadur conducted research on three continents and examined masses of files in the colonial archives. The result is a rich and gendered study of the complex lives of indentured women, many of whom were fleeing into indenture to escape some form of mistreatment in India. They were subjected to further hardship during the voyage and in the colonies. This is a story of double diaspora as her descendants migrated to the United States.

Recent work on indenture examines culture, religion, family, leisure-time activities and resistance and accommodation. Another line of academic studies highlights the 'advantages' gained by indentured Indians in the colonies. They and later their descendants most likely enjoyed greater freedom and opportunities in the colonies than they would have had in India where caste, superstition, famine and religious strictures in particular severely circumscribed life chances. There is a caveat. We need to guard against romanticising the experiences of indentured Indians, and all subaltern history for that matter; a trap that is easy to fall prey 
to. We must, by all means, validate subaltern experience by retrieving their voices, but the stories that emerge do not necessarily make these individuals heroic or the system any less harsh. Future studies should aim to find a middle path between indicting the system and pointing to ways in which the indentured used it to make new lives.

Despite the advances in the historiography, several avenues of enquiry need further exploration. One area of great importance in Fiji and other colonies that received indentured labour, including Natal, is the relationship between Indians and the indigenous populations during the colonial period and into the present. This area has been probed to some extent by Caribbean scholars but much greater research is required in most former colonies because of the repercussions that persist to the present. Fatima Meer wrote that the presence of indentured Indians in Natal undermined the negotiating power of the Zulu vis-à-vis white settlers. Whatever the African 'perceptions of Indian indentured workers was in 1860', she wrote, 'included in it must have been the suspicion, if not the knowledge, that they had been brought in ... to be used against them in ways perhaps not immediately understood' (F. Meer 1985: 48). In this regard, Desai and Vahed's (2016) revisionist study of Gandhi's South African years created a huge storm and much anger amongst Indian South Africans because it challenged the idea of Gandhi as a non-racial icon of the struggle against white minority rule in South Africa.

Walton Look Lai (1993) also addresses the poor relations between Africans and Indians, who were resented by Afro-Caribbeanists during and after indenture, while Bridget Brereton's (1979) study of Trinidad examines the colonial period. However, much work remains to be done. As Antoinette Burton reminds us:

The will to a color-blind account of solidarities between Africans and Indians in the service of a transnational or global history of political resistance is in danger of disappearing important and often painful histories of racial dis-ease-histories that were the result of Gandhian legacies, British imperial policies, caste politics and local interactions between communities of color on the ground in various parts of Africa itself (Burton 2012: 14).

In Guyana, Fiji, South Africa, Trinidad and Tobago and elsewhere, the relations between formerly subaltern groups have not been resolved, as new global forces generate new kinds of tensions that often manifest as 'race' tensions. The focus on agency and resistance is important in 
the study of indenture, motivated as it is by the desire to show how the indentured labourers lived out of the gaze of their masters. But the indentured spent the major portion of their time working, not resisting or engaging in leisure activities. Since work was so important in their lives and occupied so much of their time, in order to focus on the 'lived' experience of the indentured we need, again, to focus in detail on their work, on what they did and how it evolved, and on labour routines and discipline on plantations. Work influenced so many other aspects of the lives of the workers-family, mortality, formation of community and leisure. They were not simply involved in a perennial struggle with their masters (resistance) and a labour history perspective on indenture will allow us to see how work influenced other aspects of workers' lives.

Research on Indian indenture would also benefit from examining the indentured experience in all of its manifestations, which should include the trades in and activities of African, Chinese, Comorian, Javanese, Japanese, Malagasy, Melanesian, Yemeni and others who participated in the indentured labour system. Focusing strictly on the Indian indentured experience creates an intellectual parochialism and distorts our understanding of the richly complex global indentured experience. If we do not study indentured labour as the global phenomenon that it was, the field of Indian indenture will be marginalised in global labour studies. Moreover, Indian indenture was part of bonded labour systems that included slavery and convict labour. During the eighteenth and nineteenth centuries, most of this labour was unfree and we can gain a deeper understanding of labour history through a comparative perspective.

While much research remains to be done, the flourishing historiography of Indian indenture will undoubtedly be a source of great joy to Lal. Michael Frisch writes in his book $A$ Shared Authority that the main concern of public historians should be 'a fundamental commitment to the importance of that verb at the heart of memory, making it something alive and active as we confront our own world' (1990: 25). Lal, too, believes that a public historian's role should be to ensure that people do not forget the past, however painful that memory may be. He wrote in Intersections, 'I have done so [written his memoirs] principally in response to requests from complete strangers from around the world seeking information and reading material about their parents' and grandparents' place of birth' (Lal 2011: 6). At a public address on Fiji Remembrance Day in 2014, Lal said: 
One of my life's ambition[s] has been to remember what others have forgotten or chosen to forget - to give our people a voice and a modicum of humanity, to give them a place at the table of history. We need to remind the new generation about our history: history doesn't only belong to the victors but to the vanquished as well. One thing I have done in life before I go is to give voiceless people a voice-a sense of place, a sense of purpose. People will remember this aspect by history. I do not celebrate struggles and sacrifices and sufferings of our people. What I marvel at is how ordinary people did extraordinary things in extraordinary circumstances. We, their descendants, have inherited those traits and legacy of our forebears. And that is that even in difficult circumstances, we never give up and we never compromise. There is a kind of dignity within us, where did it come from? It comes from people who travelled thousands of miles in difficult circumstances, but never gave up. This is the legacy of Girmit that I think we are celebrating, not those horrible things we read in books many years ago (Lal 2014).

There are many things to admire in Lal's scholarship-his deep love of documents and archives, his political commitment, his sober but occasionally partial style when he feels it is warranted, his erudite scholarship, his ability to be both irreverent and reverent, his ability to theorise but refusal to let it encumber his narrative, and his desire to place the subalterns at the centre of broader historical processes.

Lal has sometimes been seen as an empiricist and criticised for not writing highly theorised history, perhaps of the likes of Gayatri Spivak or Dipesh Chakrabarty. What is wrong with this? Too often, historical writing is judged on how abstract it is and how much theory it incorporates. History is about people and the strength of Lal's work is his ability to put human faces to our pasts, and to present characters with whom his readers can connect. This kind of history gives voice to the perspectives of ordinary men and women who in the past were neglected or suppressed for one reason or other-class, age, gender, race, ethnicity. Lal's project of telling the stories of ordinary and not so ordinary people in ways that are accessible to the wider public is important as we are living in a time when the academy valorises academic journals that are never read by those who feature in these stories. There is, unfortunately, little incentive in the academy to produce the kind of meaningful work produced by Lal.

Lal has contributed significantly to various historiographies through his books, edited collections, journal articles and conference presentations in what is an accomplished career in the academy and in public life. 
His work blends autobiography and biography with social, political and historical analysis, and is both engaging and eminently readable. His books display impeccable scholarship on a range of subjects-indenture, his travels, academic life, the Indian diaspora and the discipline of History itself. His writing of history is not a passive response to the historical past. For him, the personal is historical. He actively engages with the past and present as a result of his experiences at the hands of the political elite in Fiji. He brings his own experiences to bear in his later writings as a result of his being a 'twice migrant'. He makes the point that the centre of gravity of many Fijian Indians is now the major cities of Australia and New Zealand. His magnum opus on Fiji Indians could well be subtitled 'from immigration to emigration'.

During March 2017, the Girmit Centre in Lautoka, Fiji, hosted an international conference on the abolition of Indian indenture, which I attended. This was my first trip to the country and I wrote to Lal in advance to ask whether he would also be attending. He replied on 4 November 2016:

I don't think they will lift the ban. It is so silly. I lecture to students in Fiji via skype. They see my face, hear my voice, read my words and discuss my ideas and yet the government won't allow us in. It is petty vindictiveness, nothing more, especially as last week the government lifted travel bans on foreign journalists once banned from Fiji. I may not be present physically but my spirit will be there. They can banish me but they can't ignore my work.

Sadly, Lal was not given permission to attend the conference. I found this ironic, as the overriding theme at the conference was unity and reconciliation between Indo and indigenous Fijians.

The archives that Brij V. Lal minted, the oral histories that he recorded, the fields that his ancestors tilled and out of which he harvested the history of indenture, may no longer be his domain. But true to his indentured roots, he will remain a voice to be reckoned with in the land of his birth, Fiji; in Australia, his adopted home, and in many other parts of the world where he and his work are both appreciated and respected. 


\section{References}

Arendt, Hannah. 1968. Men in Dark Times. San Diego, New York and London: Harcourt, Bruce and Co.

Bahadur, Gaiutra. 2013. Coolie Woman: The Odyssey of Indenture. London: C. Hurst.

Bhana, Surendra. 1991. Indentured Indian Emigrants to Natal, 1860-1902. New Delhi: Promilla.

Bissoondoyal, Uttama and S.B.C. Servansing (eds). 1986. Indian Labour Immigration. Moka, Mauritius: Mahatma Gandhi Institute.

Blackburn, Robin. 1997. The Making of New World Slavery: From the Baroque to the Modern, 1492-1800. London: Verso.

Brereton, Bridget. 1979. Race Relations in Colonial Trinidad. New York: Cambridge University Press.

Burton, Antoinette. 2012. Black Over Brown: Race and the Politics of Postcolonial Citation. Gurgaon, India: Three Essays Collective.

Carter, Marina. 1995. Servants, Sirdars and Settlers: Indians in Mauritius, 1834-1874. Delhi: Oxford University Press.

—_. 1996. Voices from Indenture: Experiences of Indian Migrants in the British Empire. Leicester: Leicester University Press.

Carter, Marina and Khal Torabully. 2002. Coolitude: An Anthology of the Indian Labour Diaspora. Anthem South Asian Studies.

Chaturvedi, Vinayak (ed.). 2000. Mapping Subaltern Studies and the Postcolonial, 2nd ed. London and New York: Verso.

Cumpston, I.M. 1953. Indians Overseas in British Territories, 1834-1854. London: Oxford University Press.

Dabydeen, David and Brinsley Somaroo (eds). 1987. India in the Caribbean. London: Hansib/University of Warwick, Centre for Caribbean Studies Publication in cooperation with the London Strategic Policy Unit. 
Desai, Ashwin and Goolam Vahed. 2010. Inside Indian Indenture: A South African Story, 1860-1914. Cape Town: HSRC (Human Sciences Research Council) Press.

- 2016. The South African Gandhi: Stretcher-Bearer of Empire. Stanford: Stanford University Press.

Elliott, Gregory. 2006 [1987]. Althusser: The Detour of Theory. New York: Verso.

Frisch, Michael. 1990. A Shared Authority: Essays on the Craft and Meaning of Oral and Public History. New York: State University of New York Press.

Genovese, Eugene D. 1976. Roll, Jordan, Roll: The World the Slaves Made. New York: Vintage Books.

Gillion, K.L. (Kenneth Lowell Oliver). 1962. Fijis Indian Migrants: A History to the End of Indenture in 1920. Melbourne: Oxford University Press.

Holland, Owen and Eoin Phillips. 2013. 'Fifty years of E.P. Thompson's The Making of the English Working Class'. Social History, 39(2): 172-81. DOI: 10.1080/03071022.2014.914784.

Jayawardena, Chandra. 1968. 'Migration and social change: A survey of Indian communities overseas'. Geographical Review, 58(3): 426-49. DOI: $10.2307 / 212565$.

Kale, Madhavi. 1998. Fragments of Empire: Capital, Slavery and Indian Indentured Labour in the British Caribbean. Philadelphia: University of Pennsylvania Press.

Kondapi, C. 1951. Indians Overseas, 1838-1949. New Delhi: Oxford University Press.

Lal, Brij V. 1980. 'Leaves of the banyan tree: Origins and background of Fiji's North Indian indentured migrants, 1879-1916', 2 vols. PhD thesis, The Australian National University.

- 1983a. Girmityas: The Origins of the Fiji Indians. Canberra: The Journal of Pacific History. 
—_. 1983b. 'Indian indenture historiography: A note on problems, sources and methods'. Pacific Studies, 6(2): 33-50.

—. 2000. Chalo Jahaji: On a Journey through Indenture in Fiji. Canberra: Division of Pacific and Asian History, The Australian National University; and Suva: Fiji Museum.

—_. 2001. Mr Tulsis Store: A Fijian Journey. Canberra: Pandanus Books.

—_. 2011. 'When it is over'. In Intersections: History, Memory, Discipline, pp. 1-7. Lautoka: Fiji Institute of Applied Studies; and Sydney: Asia Pacific Publications.

—_. 2014. 'Fiji girmitiyas: Ordinary people did extraordinary things in extraordinary circumstances'. Address on Girmit Remembrance Day, Auckland, 17 May 2014. Transcript and translation from Hindi by Thakur Ranjit Singh. In Fiji Pundit, 17 May 2014. Online: fijipundit. blogspot.com/2014/07/fiji-girmitiyas-ordinary-people-did.html (accessed 7 September 2014).

Lal, Brij V. (ed.). 2004. Bittersweet: The Indo-Fijian Experience. Canberra: Pandanus Books.

- - (ed.). 2006. The Encyclopaedia of the Indian Diaspora. Singapore: Editions Didier Millet in association National University of Singapore. Lautoka: Fiji Institute of Applied Studies; and Sydney: Asia Pacific Publications.

Look Lai, Walton. 1993. Indentured Labor, Caribbean Sugar: Chinese and Indian Migrants to the British West Indies, 1838-1918. Baltimore: The Johns Hopkins University Press.

Mangru, Basdeo. 1996. A History of East Indian Resistance on the Guyana Sugar Estates, 1869-1948. New York: Edwin Mellen Press.

Meer, Fatima. 1985. 'Indentured labour and group formation in apartheid society'. Race \& Class, 26(4): 45-60.

Meer, Y.S. (ed.). 1980. Documents of Indentured Labour in Natal, 1851-1917. Durban: Institute for Black Research.

Mesthrie, Rajend. 1991. Language in Indenture: A Sociolinguistic History of Bhojpuri-Hindi in South Africa. Johannesburg: Witwatersrand University Press. 
Mills, C. Wright. 2000. The Sociological Imagination. Oxford: Oxford University Press.

Munro, Doug. 2009. The Ivory Tower and Beyond: Participant Historians of the Pacific. Newcastle-upon-Tyne: Cambridge Scholars Publishing.

Nelson, Cary and Lawrence Grossberg (eds). 1988. Marxism and the Interpretation of Culture. Urbana: University of Illinois Press.

Northrup, David. 1995. Indentured Labor in the Age of Imperialism, 1834-1922. Cambridge: Cambridge University Press.

Ramesar, Marianne. 1994. Survivors of Another Crossing: A History of East Indians in Trinidad, 1880-1946. Mona, Jamaica: University of the West Indies, School of Continuing Studies.

Reddock, Rhoda. 1994. Women, Labour and Politics in Trinidad and Tobago: A History. London: Zed Books.

Roopnaraine, Lomarsh. 2007. Indo-Caribbean Indenture: Resistance and Accommodation. Kingston: University of West Indies Press.

Scott, James C. 1985. Weapons of the Weak: Everyday Forms of Peasant Resistance. New Haven: Yale University Press.

Singh, Hira. 2014. Recasting Caste: From the Sacred to the Profane. New Delhi: Sage Publications.

Spivak, Gayatri Chakravorty. 1988. 'Can the subaltern speak?'. In Marxism and the Interpretation of Culture, edited by Cary Nelson and Lawrence Grossberg, pp. 271-313. Urbana: University of Illinois Press.

Stampp, Kenneth. 1956. The Peculiar Institution: Slavery in the Antebellum South. New York: Alfred A. Knopf.

Stoler, Ann Laura. 2009. Along the Archival Grain: Epistemic Anxieties and Colonial Common Sense. Princeton: Princeton University Press.

Thompson, E.P. 1963. The Making of the English Working Class. London: Victor Gollancz.

Thompson, L.M. 1952. Indian Immigration into Natal, 1860-1872. Pretoria: Union Archives Printer. 
Tinker, Hugh. 1974. A New System of Slavery. The Export of Indian Labour Overseas, 1830-1920. London: Oxford University Press.

Vahed, Goolam. 2007. 'Adaptation and integration of Indian migrants in Brisbane, Australia'. In Indian Diaspora-The 21st CenturyMigration, Change and Adaptation, edited by Anand Singh. Special issue of The Anthropologist, 2: 37-51.

Vahed, Goolam. 2015. 'Nehru is "just another coolie": India and South Africa at the United Nations, 1946-1955'. In Conceptualising the Roles of China and India in Africa: History, Contemporary Realities and Future Scenarios. Special issue of Alternation Journal, 15: 54-85.

Vahed, Goolam and Surendra Bhana. 2006. 'Indians in South Africa.' In The Encyclopedia of the Indian Diaspora, edited by Peter Reeves, Brij V. Lal and Rajesh Rai, pp. 242-53. Singapore: Editions Didier Millet in association National University of Singapore; Lautoka: Fiji Institute of Applied Studies; and Sydney: Asia Pacific Publications.

Waetjen, Thembisa and Goolam Vahed. 2014. 'Passages of ink: Decoding the Natal indentured records into the digital age'. Kronos, 40(1): 45-73. Online: www.scielo.org.za/pdf/kronos/v40n1/03.pdf (accessed 6 March 2017).

Weller, Judith Ann. 1968. The East Indian in Trinidad. Rio Piedras: Institute of Caribbean Studies, University of Puerto Rico. 
This text is taken from Bearing Witness: Essays in honour of Brij V. Lal, edited by Doug Munro and Jack Corbett, published 2017 by ANU Press, The Australian National University, Canberra, Australia. 